\section{Taxane and ABA Production in Yew under Different Soil Water Regimes}

Angela Hoffman

Department of Chemistry and Physics, University of Portland, Portland, OR 97203

\section{Clinton Shock and Erik Feibert Malheur Experiment Station, Oregon State University, Ontario, OR 97914}

Additional index words. Taxol, paclitaxel, abscisic acid, Taxus $\times$ media, soil water potential, water stress, stomata

\begin{abstract}
Taxol ${ }^{\circledR}$ (paclitaxel), an important anticancer agent, is found in many species of yew. As the need for Taxol increases, sustainable sources must be found for this drug. Plants often respond to stress with increased production of terpenoid compounds such as Taxol and related taxanes or hormones such as abscisic acid (ABA). To determine whether water stress would enhance the production and recovery of Taxol from stem clippings, 100 young Taxus $\times$ media 'Hicksii' shrubs were grown for sustainable production of Taxol from stem clippings for two seasons in the dry climate of the Malheur Experiment Station in Ontario, Ore. Shrubs were grown under minimal, moderate, or severe water stress, and the relationships between taxane content and 1) soil and plant water potentials, 2) percentage of stomatal closure, and 3) ABA content were examined. Severely waterstressed shrubs produced significantly more taxanes and ABA than did the less stressed shrubs. Chemical names used: Taxol; 10-deacetyl baccatin III; baccatin III; 10-deacetyl taxol, cephalomannine; 7-epi; 10-deacetyl taxol; abscisic acid. Taxol is a registered trademark of Bristol-Myers Squibb.
\end{abstract}

Taxol® (paclitaxel) from bark of the Pacific yew tree, Taxus brevifolia Nutt., is an effective anticancer drug identified in the 1960s (Wani et al., 1971). This slow-growing tree is native to the temperate northwestern United States and adjacent Canada (Hitchcock et al., 1961). Yew bark typically contains 10 to 500 $\mu \mathrm{g} \cdot \mathrm{g}^{-1}$ of Taxol on a dry-weight basis (Wheeler et al., 1992) depending on clonal variation, tissue position, and timing during the season (Vance et al., 1994). Taxol is also found in small twigs, roots, and needles of T. brevifolia and several other Taxus species (Kelsey and Vance, 1992, Mattina and Paiva, 1992; Wickremesinhe and Arteca, 1994). A number of the species available from commercial nurseries grow faster than the native species and produce useful amounts of Taxol (Hansen et al., 1994; Vidensek et al., 1990).

Other diterpenoid compounds with a complex ring structure similar to Taxol (Fig. 1), collectively known as "taxanes," are found in many yew species. Although they generally have no anticancer activity, they may be converted to Taxol (Georg et al., 1992; Gunatilaka et al., 1997; Khmelnitsky et al., 1997). For example, 10-deacetyl baccatin III may be ob-

Received for publication 12 Mar. 1998. Accepted for publication 2 Nov. 1998. Oregon State Publication No. 11306. We thank the Agricultural Research Foundation for financial support. The help and support of the following students is appreciated: Tammy Hanna, Abbey Heck, Amanda Kirk, Matt Lampa, Dinh Tuan Le, and Robin Rasmussen. The cost of publishing this paper was defrayed in part by the payment of page charges. Under postal regulations, this paper therefore must be hereby marked advertisement solely to indicate this fact. also favor the synthesis of abscisic acid (ABA) which affects root growth and stomatal aper-

Fig. 1. Chemical structure of Taxol and related taxanes. ture (Close and Bray, 1993) and may inhibit plant growth (Nonami et al., 1997). Drought appears to stimulate ABA synthesis in roots (Zhang and Davies, 1989). The ABA may move with the transpiration stream to the leaf where it causes closure of guard cells to prevent turgor loss. In certain types of plants, if the water loss is so great that leaves begin to dehydrate, additional ABA may be produced in older leaves and transported to younger ones where it helps maintain turgor and prevent desiccation (Davies et al., 1994).

The objective of this project was to study the effects of water stress on the production of taxanes and ABA in Taxus $\times$ media 'Hicksii', a yew cultivar with high Taxol® content (Hansen et al., 1994).

\section{Materials and Methods}

Plant material. Cutting-propagated yew shrubs (Taxus ×media 'Hicksii' Rehd.), $\approx 0.6$ $\mathrm{m}$ tall, were obtained from Zelenka Nursery, Inc., Grand Haven, Mich. They were planted $1.22 \mathrm{~m}$ apart in rows $3.05 \mathrm{~m}$ apart on 3 May 1996 in an Owyhee silt loam (coarse-silty, mixed, mesic, Xerollic Camborthid) at the Malheur Experiment Station, Oregon State Univ., in Ontario, Ore.

Irrigation. The shrubs were irrigated uniformly for 2 months after planting using furrow irrigation, after which they were subjected to one of three irrigation rates using drip irrigation. Starting 15 July 1996, one drip tape (Turbulent Twin Flow, Chapin Watermatics, Watertown, N.Y.) with emitters spaced $0.3 \mathrm{~m}$ apart was used along each row (flow rate of 36 $\mathrm{mL} \cdot \mathrm{min}^{-1} \cdot \mathrm{m}^{-1}$ of tape at $66 \mathrm{kPa}$ water pressure). The treatment rates were $28 \mathrm{~mm}$ (minimally stressed), $19.6 \mathrm{~mm}$ (moderately stressed, $70 \%$ of $28 \mathrm{~mm}$ ), and $11.2 \mathrm{~mm}$ (severely stressed, $40 \%$ of $28 \mathrm{~mm}$ ) applied at each

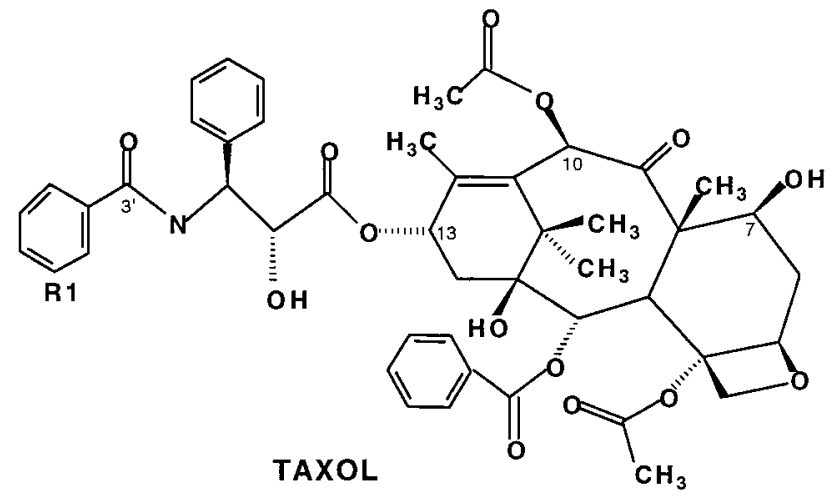
1 10-deacetyl Baccatin III: $\mathrm{C}-13=\mathrm{OH} ; \mathrm{C}-10=\mathrm{OH}$
2 Baccatin III: $\mathrm{C}-13=\mathrm{OH}$
3 7-epi-10 deacetyl Taxol: $\mathrm{C} 7=$ epimer; $\mathrm{C}-10=\mathrm{OH}$
4 Cephalomannine: $\mathrm{R} 1=\mathrm{C}_{4} \mathrm{H}_{9}$
5 10-deacetyl Taxol: $\mathrm{C}-10=\mathrm{OH}$
6 Paclitaxel (shown) 
irrigation, corresponding to $34.2,23.9$, and 13.7 $\mathrm{L}$ per shrub per irrigation. The rates were calculated based on a 1-m-wide bed for each row. Water was applied to plots one row (shrub) wide and five shrubs long arranged in a complete randomized-block design with four blocks. The total water applied was measured for each irrigation treatment using water meters.

All plots were irrigated when the average soil water potential (SWP) at a $0.2-\mathrm{m}$ depth in the minimally stressed plots reached $-40 \mathrm{kPa}$ in 1996 and $-60 \mathrm{kPa}$ in 1997 . Two granular matrix sensors (GMS, Watermark Soil Moisture Sensor Model 200SS, Irrometer Co., Riverside, Calif.) were installed at a 0.2-m depth in line with the shrubs in each plot. The GMS were previously calibrated to measure SWP (Shock et al., 1998). All GMS were connected via multiplexers (AM 410 multiplexer, Campbell Scientific, Logan, Utah) to a datalogger (CR 10 datalogger, Campbell Scientific). The SWP was recorded daily at $8 \mathrm{AM}$ from 18 July to 28 Aug. 1996 and from 3 June to 28 Aug. 1997.

The shrubs were irrigated according to the treatment criteria on 15 July, 8 Aug., and 22 Aug. 1996, and on 25 June, 11 July, 28 July, 9 Aug., and 24 Aug. 1997. Based on 1-m-wide beds, a total of 134, 109, and $84 \mathrm{~mm}(163,133$, and $102 \mathrm{~L}$ per shrub) in 1996 , and 237,192 , and $154 \mathrm{~mm}(289,234$, and $188 \mathrm{~L}$ per shrub) in 1997 were applied to the 28-, 19.6-, and $11.2-\mathrm{mm}$ treatments, respectively. These amounts of water include $50 \mathrm{~mm}$ applied to all treatments after the last sampling date each year and $50 \mathrm{~mm}$ applied uniformly during May 1997.

Harvesting methods and schedules. Each summer, twigs with leaves and stems (6- to 8$\mathrm{cm}$ lengths) were taken from each plot individually before the variable irrigation treatments began, and about every 3 weeks during the remainder of the irrigation season. Samples were taken from each of the middle three shrubs in each plot of five shrubs on 30 June, 29 July, 14 Aug., and 30 Aug. 1996 and on 1 June, 7 July, 15 July, 28 July, 12 Aug., and 26 Aug. 1997. All samples were frozen immediately and transported overnight on dry ice to the Univ. of Portland for analysis. If not analyzed upon arrival, they were stored at $-80^{\circ} \mathrm{C}$. Twigs were sampled each day during the irrigation cycle from 14 July to 29 July 1997 to determine the relationship between plant water potential and SWP. One or two plots from each treatment were selected. A psychrometer was used to measure air temperature and relative humidity at the time of sampling. Twigs 8 $\mathrm{cm}$-long were immediately enclosed in plastic bags and stored on ice in a cooler and transported to a laboratory close to the field. Plant water potential was measured using a Scholander pressure chamber (PMS Instruments Co., Corvallis, Ore.). As the cuttings were collected, the backs of some needles on shoots of the same plants were painted with clear fingernail polish. The painted shoots were immediately cut, packed on dry ice, and sent to the Univ. of Portland. Upon arrival in Portland, the polish was peeled off and photographed using a Sony CCD-iris/RGB color video camera attached to an Olympus $\mathrm{CH}-2$ microscope with a $40 \times$ power objective eyepiece. The images were viewed with a digital SCSI (Computer Eyes) video frame grabber on a Macintosh Power PC using NIH Image.

Taxol and abscisic acid determination. Taxol and other taxanes were analyzed as described by Hoffman et al. (1996). Briefly, 10 to $15 \mathrm{~g}$ of plant material were randomly selected from samples from each plot. Eight to $10 \mathrm{~g}$ of the tissue were ground with a coffee grinder and extracted with methanol. The solvent was evaporated under reduced pressure at $35{ }^{\circ} \mathrm{C}$ and the residue mixed with water. The lipids, chlorophyll, and other hydrophobic compounds were removed by extraction into hexane. Taxol, ABA, and related compounds were removed from the aqueous mixture by passage through a C-18 Sep Pak cartridge (Waters, Milford, Mass.), then eluted with methanol. The methanol was evaporated and the residue was dissolved in a known amount of methanol, filtered, and chromatographed on reverse-phase HPLC. The taxanes were quantified using calibration curves of authentic standards. Statview (Abacus Concepts, Inc., Berkeley, Calif.) was used for statistical analyses. Efficiency of taxane and ABA extraction was estimated in duplicate by measuring the recovery of $\mathrm{ABA}$ and Taxol from spiked plant samples. Recovery was $\approx 88 \%$ for $\mathrm{ABA}$ and $80 \%$ for Taxol.

The tissue not used for extraction was dried in an oven at $110^{\circ} \mathrm{C}$. The difference between fresh and dry weight was calculated for each plot.
HPLC separation methods. Taxane separation was accomplished using either a Curosil $\mathrm{B}$ or PFP (Phenomenex, Torrance, Calif.) analytical column $(5 \mu \mathrm{m})$. Isocratic conditions for separation were $55 \%$ A $(10 \mathrm{~mm}$ ammonium acetate, $\mathrm{pH} 4.0$ ) and 45\% B (HPLC grade acetonitrile) at a flow rate of $1 \mathrm{~mL} \cdot \mathrm{min}^{-1}$ at 228 $\mathrm{nm}$. Three $10-\mu \mathrm{L}$ injections were made for each sample. To aid in peak identification, one injection for each sample was spiked with a mixture of 0.4 to $0.6 \mu \mathrm{g}$ each of six taxanes (10-deacetyl baccatin III, baccatin III, 10deacetyl taxol, cephalomannine, 7 epi, 10deacetyl taxol, Taxol). Taxane standards were purchased from Hauser Laboratories, Boulder, Colo. A C-18 analytical HPLC column (Dynamax, Rainin/Varian) was used to separate and quantify ABA using isocratic conditions: 55\% A (HPLC grade methanol) and $45 \%$ B: (1\% acetic acid). Flow rate was 1 $\mathrm{mL} \cdot \mathrm{min}^{-1}$. Taxanes were quantified by their absorption at $245 \mathrm{~nm}$. Three $10-\mu \mathrm{L}$ injections were made for each sample. To aid in peak identification, one injection for each sample was spiked with authentic ABA (Sigma, St. Louis).

\section{Results and Discussion}

Establishment of handling procedures. Handling procedures were evaluated for harvesting and transporting samples from Ontario, Ore., to Portland, Ore. Samples stored in liquid nitrogen $\left(175 \pm 25 \mu \mathrm{g} \cdot \mathrm{g}^{-1}\right)$ or on dry ice $\left(192 \pm 26 \mu \mathrm{g} \cdot \mathrm{g}^{-1}\right)$ had higher Taxol content than those that were oven-dried $\left(51 \pm 15 \mu \mathrm{g} \cdot \mathrm{g}^{-1}\right)$.

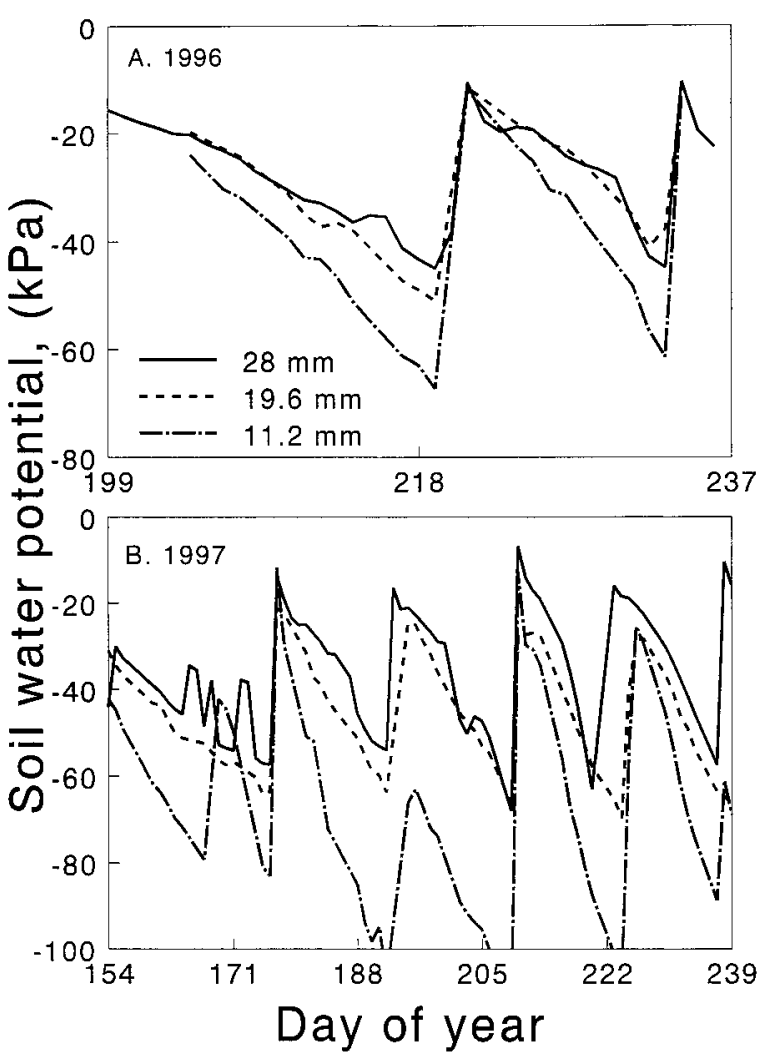

Fig. 2. Water potential monitored at 0.2-m depth from (A) 18 July through 28 Aug. 1996 and (B) 1 June through 24 Aug. 1997. Plants were watered when the soil water potential for the " $28 \mathrm{~mm}$ " treatment reached -40 kPa during 1996 and -60 kPa during 1997. 
Table 1. Effect of water stress on the concentration of Taxol recovered in 'Hicksii' yew cuttings on 14 and 30 Aug. 1996 at Ontario, Ore.

\begin{tabular}{lcc}
\hline \hline Stress & Sample no. & Taxol $\left(\mu \mathrm{g} \cdot \mathrm{g}^{-1} \mathrm{DW}^{\mathrm{y}}\right)$ \\
\hline \multicolumn{2}{c}{14 Aug. } & \\
Minimal & 8 & 71 \\
Moderate & 12 & 364 \\
Severe & 12 & 115 \\
LSD $_{0.05}$ & & 289 \\
& 30 Aug. & \\
Minimal & 8 & 44 \\
Moderate & 12 & 114 \\
Severe & 12 & 124 \\
LSD $_{0.05}$ & & 68 \\
\hline Shrubs & &
\end{tabular}

${ }^{\mathrm{z} S h r u b s}$ were irrigated on 15 July, 8 Aug., and 22

Aug.

${ }^{\mathrm{y}} \mathrm{DW}=$ dry weight.

Some of the oven-dried cuttings yielded little or no Taxol, but Taxol was found in the corresponding samples transported on liquid nitrogen or dry ice. All subsequent samples were collected and immediately placed in a cooler with dry ice and transported overnight in the cooler. The samples were either analyzed immediately upon arrival or stored at $-80^{\circ} \mathrm{C}$.

Responses to water stress. Tissue samples were harvested and analyzed four times during Summer 1996 and six times during Summer 1997. The samples were generally taken just before irrigation when SWP was lowest (Fig. 2) and moisture stress was highest. There were several important differences between the field conditions in 1996 and 1997. First, the plants had better established root systems in 1997, so the data were probably more reliable and consistent. Secondly, the SWP used as an irrigation criterion was $-60 \mathrm{kPa}$ in $1997 \mathrm{vs}$. $-40 \mathrm{kPa}$ in 1996. There was a greater difference between SWP in severely stressed and minimally stressed shrubs in 1997 than in 1996. This difference was apparently large enough to affect plant $\mathrm{ABA}$ and Taxol content.

During the irrigation cycle between 14 and 28 July 1997 (days 192 through 209) there was a strong positive correlation between SWP (X in $\mathrm{kPa}$ ) and plant water potential ( $\mathrm{Y}$ in $\mathrm{kPa}) ; \mathrm{Y}$ $=921.6+16.9 \mathrm{X}, r^{2}=0.57, P \leq 0.001$. Since GMS readings of SWP were not calibrated below $-75 \mathrm{kPa}$ (Eldredge et al., 1993; Shock et al., 1998), more negative values were not included in the calculation. When the samples were harvested for taxane and ABA extraction on 28 July 1997, needles were also collected for stomatal analysis. Only a few stomata were open on any plants, and none were open on those that were most stressed. Stomata from all the leaves were essentially the same size. The ABA concentration tended to be higher in shoots from plants grown on plots with more negative SWP; these were also the plants with the fewest open stomata.

Taxane and ABA analysis. The amounts of Taxol recovered varied throughout Summer 1996 when the plants were becoming established. On 14 Aug., significantly more Taxol was obtained from plants in moderately waterstressed plots than from those in the other treatments (Table 1). Variability was high $\left(\mathrm{LSD}_{0.05}=289\right)$, possibly due to seasonal and weather differences, plant to plant variation,
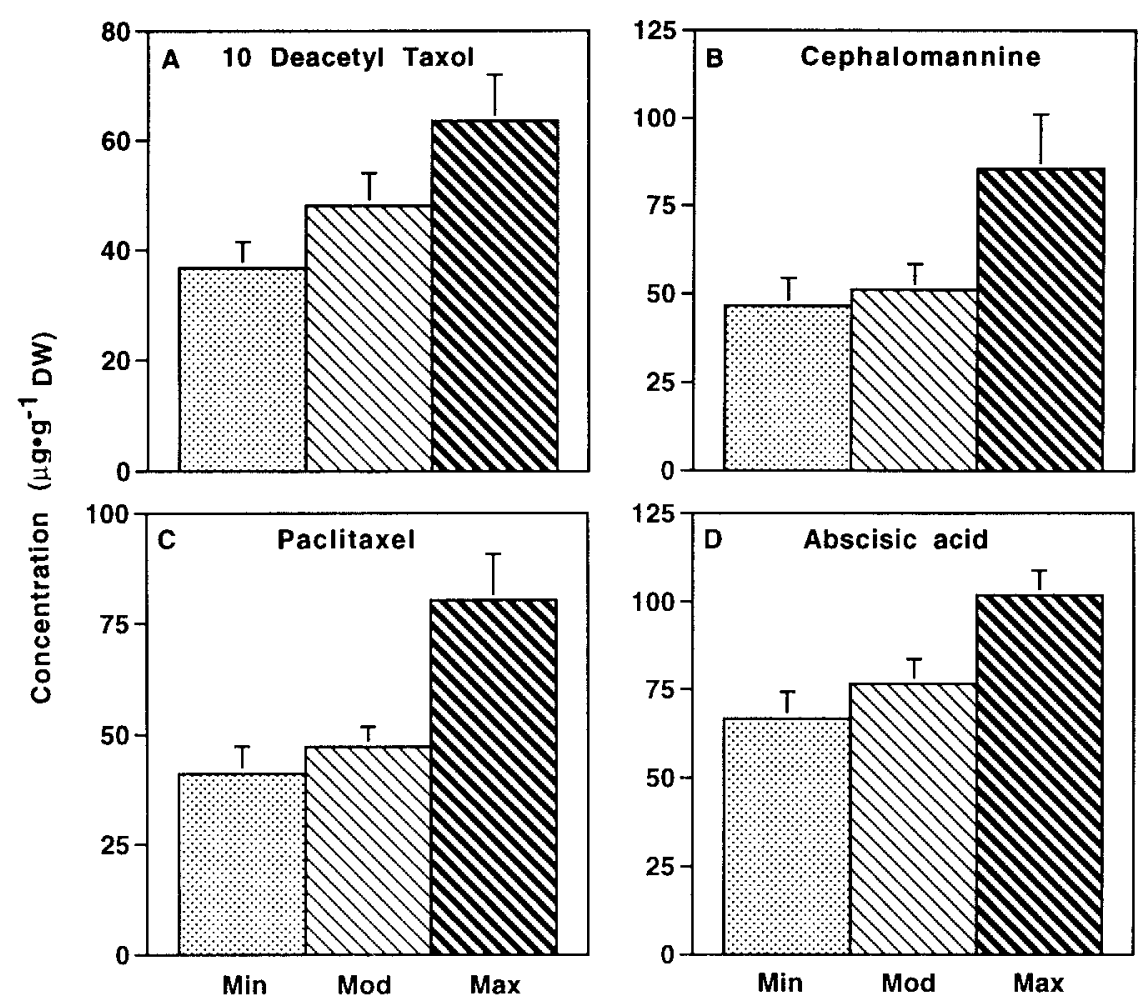

Water Stress

Fig. 3. Effects of water stress (minimum, moderate, maximum) on recovery of (A) 10 deacetyl Taxol, (B) cephalomannine, (C) Taxol, and (D) abscisic acid from 'Hicksii' yew cuttings harvested between 7 July and 26 Aug. 1997. The error bars indicate the standard errors of the mean.
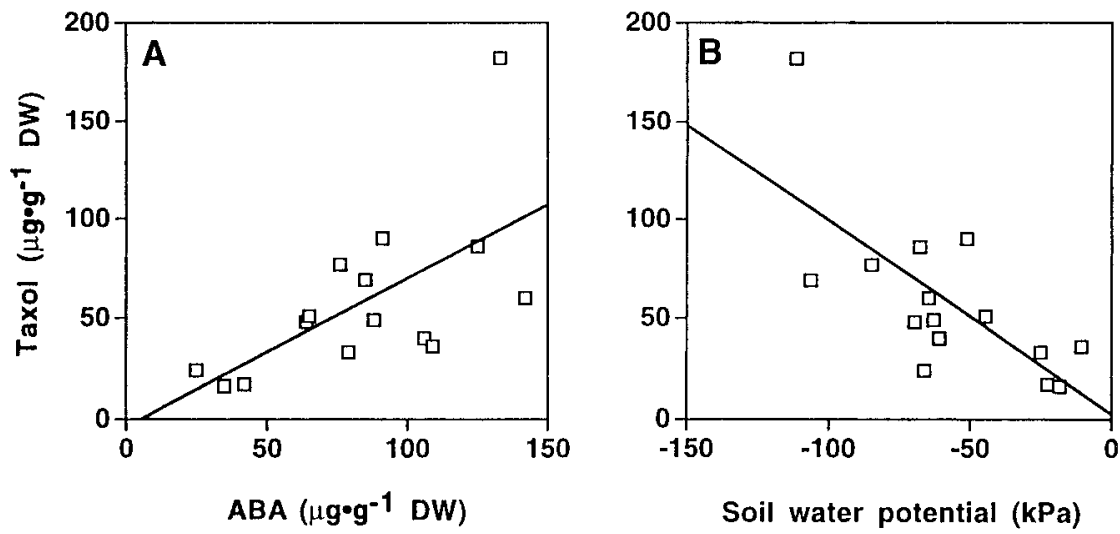

Fig. 4. The relationship between concentration of Taxol in 'Hicksii' yew cuttings harvested between 7 July and 25 Aug. 1997 and (A) ABA concentration in cuttings and (B) soil water potential (kPa).

and the fact that root systems were still becoming established. On $30 \mathrm{Aug}$., plants in both the moderately and severely stressed plots contained more taxol than those in the minimally stressed plots.

In 1997, after the plants were better established, the irrigation criterion was lowered to $-60 \mathrm{kPa}$. The amount of Taxol recovered still varied considerably throughout the summer, but the pattern of recovery had changed (Fig. 3 ). The overall trend for 1997, however, was clear: both the taxanes and ABA concentrations increased with increasing stress. Plantto-plant variation, differences in plant or SWP at the time of harvest, seasonal differences in unmeasured environmental conditions, analytical error, or some combination of these may have been responsible for the variability observed.

There was a strong correlation between ABA concentration and the percentage of open stomata. This is consistent with the theory that ABA is made in response to low SWP and that ABA affects stomatal closure.

Strategy for hedge-row yew harvesting for increased Taxol production. Numerous studies have related water potential and ABA concentration in plants (Close and Bray, 1993), 
but few, if any, have related ABA content with the degree of water stress required to stimulate the accumulation of secondary compounds such as taxanes. A review by Gershenzon (1984) suggests that stress favors the synthesis of secondary metabolites in plants. For example, Catharanthus roseus Don. produced more alkaloids (also used in cancer treatment) when plant water potential dropped below 3.7 MPa compared with-1.3 MPa (Frischnecht et al., 1987). To our knowledge, the present study is the first to relate soil and plant water potential to taxane recovery from yew.

The strong correlation between the Taxol and $\mathrm{ABA}$ recovered from yew (Fig. 4A) suggests that either the conditions that stimulate ABA synthesis also stimulate Taxol synthesis or that an increase in ABA stimulates Taxol synthesis. If yew were grown as a crop, field conditions and taxane content should be monitored to determine the best time for harvesting. Routine monitoring of SWP is more practical than measuring plant water potential or $\mathrm{ABA}$ concentration. Taxane concentration was strongly correlated with SWP (Fig. 4B); as SWP decreased, the concentration of Taxol increased. One may be able to fine-tune the timing and amounts of irrigation required to keep the plant growing vigorously, yet also harvest high yields of Taxol. A SWP of about $-70 \mathrm{kPa}$ could be maintained before harvesting. 'Hicksii' yew had one growth flush in the spring, but the effects of subsequent water stress on growth is not known, nor do we know how long the plants must be water-stressed to stimulate maximum Taxol synthesis and accumulation.

\section{Literature Cited}

Close, T.J. and E.A. Bray (eds.). 1993. Plant response to cellular dehydration during environmental stresses: Current topics in plant physiology, vol. 10. Amer. Soc. Plant Physiol., Rockville, Md.

Davies, W.J., F. Tardieu, and C.L. Trejo. 1994. How do chemical signals work in plants that grow in drying soil? Plant Physiol. 104:309-314.

Eldredge, E.P., C.C. Shock, and T.D. Stieber. 1993. Calibration of granular matrix sensors for irrigation management. Agron. J. 85:1228-1232.

Elmer, W.H., M.J.I. Mattina, and G.J. MacEachern. 1994. Sensitivity of plant pathogenic fungi to taxane extracts from ornamental yews. Phytopathology 84:1179-1185.

Frischnecht, P.M., M. Bättig, and T.W. Baumann. 1987. Effect of drought and wounding stress on indole alkaloid formation in Catharanthus roseus. Phytochemistry 26:707-710.

Georg, G.I., Z.S. Cheruvallath, R.H. Himes, M.R. Mejillano, and C.T. Burke. 1992. Synthesis of biologically active taxol analogs with modified phenylisoserine sidechains. J. Med. Chem. 35:4230-4237.

Gershenzon, J. 1984. Changes in the levels of plant secondary metabolites under nutrient and water stress, p. 273-320. In: B.N. Timmermann, C. Steelink, and F.A. Loewus (eds.). Recent advances in phytochem. Vol. 18. Plenum Press, New York.

Gunatilaka, A.A.L., M.D. Chordia, and D.G.I. Kingston. 1997. Efficient conversion of cephalomannine to paclitaxel and 3'- $N$-aceyl3'- $N$-debenzoylpaclitaxel analogs. J. Org. Chem. 62:3775-3778.

Hansen, R.C., K.D. Cochran, H.M. Keener, and E.M. Croom, Jr. 1994. Taxus populations and clippings yields at commercial nurseries. HortTechnology 4:372-377.

Hitchcock, C.L., A. Cronquist, M. Ownbey, and J.W. Thompson. 1961. Vascular plants of the Pacific Northwest, part 1: Vascular cryptograms, gymnosperms and monocotyledons. Univ. of Washington Press, Seattle. p. 103.

Hoffman, A.M., C.C.J. Voelker, A.T. Franzen, K.S. Shiotani, and J.S. Sandhu. 1996. Taxanes exported from Taxus $\times$ media Hicksii cuttings into liquid medium over time. Phytochemistry 43:9598.

Kelsey, R.G. and N.C. Vance. 1992. Taxol and cephalomannine concentrations in the foliage and bark of shade-grown and sun exposed Taxus brevifolia trees. J. Nat. Prod. 55:912-917.

Khmelnitsky, Y.L., C. Budde, J.M. Arnold, A. Usyatinsky, D.S. Clark, and J.S. Dordick. 1997. Synthesis of water-soluble paclitaxel derivatives by enzymatic acylation. J. Amer. Chem. Soc. 119:11554-11555.
Mattina, M.J.I. and A.A. Paiva. 1992. Taxol concentration in Taxus cultivars. J. Environ. Hort. 10:187-191.

Nonami, H., Y. Wu, and J.S. Boyer. 1997. Decreased growth-induced water potential: A primary cause of growth inhibition at low water potentials. Plant Physiol. 114:501-509.

Saenz, L., C. Oropeza, M. Villaneuva, V. Loyola, and J. Santamaria. 1990. Effect of water deficit on the alkaloid content of plants of Catharanthus roseus L. (Don.), p. 393-395. In: W.J. Davies and B. Jeffcoat (eds.). Importance of root to shoot communication in the responses to environmental stress. Monograph 21. Brit. Soc. Plant Growth Regulat., Bristol, U.K.

Shock, C.C., J.M. Barnum, and M. Seddigh. 1998. Calibration of Watermark soil moisture sensors for irrigation management, p 139-146. In: Proc. Irr. Assoc., San Diego, Calif.

Vance, N.C., R.G. Kelsey, and T.E. Sabin. 1994. Seasonal and tissue variation in taxane concentrations of Taxus brevifolia. Phytochemistry 36:1241-1244.

Vidensek, N., P. Lim. A. Campbell, and C. Carlson. 1990. Taxol content in bark, wood, root, leaf, twig, and seedling from several Taxus species. J. Natl. Prod. 53:1609-1610.

Wani, M.C., W.H. Taylor, M.E. Wall, P. Coggon, and A.T. McPhail. 1971. Plant antitumor agents. VI. The isolation and structure of taxol, a novel antileukemic and antitumor agent from Taxus brevifolia. J. Amer. Chem. Soc. 93:2325-2327.

Wheeler, N.C., K. Jech, S. Masters, S.W. Brobst, A.B. Alvarado, A.J. Hoover, and K.M. Snader. 1992. Effects of genetic, epigenetic, and environmental factors on taxol content in Taxus brevifolia and related species. J. Nat. Prod. 55:432-440.

Wickremesinhe, E.R.M. and R.N. Arteca. 1994. Roots of hydroponically grown Taxus plants as a source of taxol and related taxanes. Plant Sci. 101:125-135.

Young, D.H., E.L. Michelotti, C.S. Swindell, and N.E. Krauss. 1992. Antifungal properties of taxol and various analogues. Experientia 48:882885.

Zhang, J. and W.J. Davies. 1989. Abscisic acid produced in dehydrating root may enable the plant to measure the water status of the soil. Plant Cell Environ. 12:73-81. 